\title{
Petrochemical Industry in India: Determinants, Challenges and Opportunities
}

\author{
Mohd Hussain Kunroo* and Keshav Soni \\ Department of Economics, Central University of Rajasthan, India \\ *Corresponding author: Mohd Hussain Kunroo, Assistant Professor, Department of Economics, Central University of Rajasthan, Bandarsindri, India.
}

Submission: 悳 February 05, 2018; Published: 侐 March 14, 2018

\begin{abstract}
Petrochemical sector is no doubt, vital for the stimulation of economic growth and development of any country, and India is not an exception. This sector needs more government assistance in technology expansion, and financial help in order to grow faster and compete with global competitors. This article presents the current scenario of the Petrochemical industry in India. It highlights nature, sources of technology and key challenges that this sector is going to face in the near future.
\end{abstract}

\section{Introduction}

Petrochemical industry plays a vital role in the economic growth of a nation. They supply basic and useful raw materials to the other industries and final goods to the individual consumers. Nowadays, petrochemical products influence the entire life and cover almost every area such as housing, clothing, agriculture, horticulture, furniture, construction, automobiles, irrigation, medical equipment, electrical and electronics, etc. Petrochemical products are derived products of several chemical materials. More specifically, hydrocarbons are the main chemical components of petrochemicals, which, in turn, are derived products of natural gas and crude oil. Also, the main feed stock for the petrochemical industry is kerosene, naphtha and gas oil. Recently, unconventional feed stocks such as shale gas, coal, coal bed methane (CBM), pet coke, etc. have also been used [1]. Other important feed-stocks used in the industry are propane, ethane, butane and Natural Gas Liquid (NGL) which are by-product of the natural gas. The basic but major raw materials from which most of the chemicals are derived are olefins (ethylene, propylene \& butadiene) and aromatics (benzene, toluene and xylene). Olefins and aromatics are the primary buildingblocks for a wide range of articles such as detergents, solvents and adhesives. It should be noted that Olefins form the basis for polymers and oligomers used in plastics, resins, fibers, elastomers, lubricants, and gels.

The basic question is: Is there any economics involved behind the manufacturing locations of petrochemicals? Yes. The answer lays in the fact that Petrochemical manufacturing units work on the idea of integrated manufacturing from all those groups of related materials that are often made in the nearby manufacturing plants with the only intension to induce industrial symbiosis as well as material and utility efficiency and other economies of scale.

The economic reforms initiated in 1991 in India brought about a significant change in domestic petrochemical industry through opening up of the economy and adopting liberalized policies. That allowed market forces to adjust automatically and achieve the desired level of growth and level of investment. It is now globally accepted that consumption of ethylene and consumption of polymer in the downstream plastic articles have strong correlations with the growth of gross domestic product (GDP) of India. Consumption of these articles has forward and backward linkages as well as has multiplier effect on the GDP growth of India. On the one hand they provide materials to the agriculture, automobiles, and manufacturing, etc. And on the other hand they provide direct and indirect job opportunities. These linkages ensure further increase in the GDP growth leading to better quality of life.

\section{Current Status of Petrochemical Sector of India}

In this globalized world, Petrochemical industry plays a prominent role in the economic growth and development of a sovereign nation. India is spread over a land mass of around 3.17 million square kilometers with a population of over 1.22 billion. Such economic characteristics lend it the character of a rapidly growing economy. Besides, it has a well-developed Processing and Manufacturing Industry related to the field of petrochemicals as it has 4 naphtha based and 4 gas based cracker complexes. Together, their ethylene capacity is 4.00 million MT (metric tons) annually. Besides these India also has 6 aromatic complexes with a combined Xylene capacity of 4.45 million MT. Out of the total production of 
major petrochemicals the production of polymers account for about $59.32 \%$ [2].

As Table 1 shows India's total installed capacity in 2015-16equals 17,702 thousand metric tons, in 2014-15 the growth rate of installed capacity was $4.02 \%$ and in the year $2015-16$ it was $5.40 \%$, whereas total production in $2015-16$ was 14,900 thousand metric tons, with a growth rate of $10.80 \%$. The utilization of plants was $84 \%$ of total installed capacity. This Table 1 also shows that there is marginal increase in installed capacities of synthetic fibers, polymers and performance plastics where as elastomers and synthetic detergent intermediates installed capacities remained same. Growth rate of all the products- except performance products- was negative in 2008-09 due to the global slowdown.

Table 1: Production, Installed Capacity \& Growth of Selected Basic Major Petrochemicals (Group-wise) during 2008-09 to 2015-16 [5]. (Figures in thousand MT)

\begin{tabular}{|c|c|c|c|c|c|c|c|c|c|c|c|c|}
\hline \multirow{2}{*}{ Group } & \multicolumn{3}{|c|}{ Installed capacity } & \multirow{2}{*}{$\begin{array}{l}\text { Production/ } \\
\text { Growth Rate }\end{array}$} & \multirow{2}{*}{$\begin{array}{c}2008- \\
09\end{array}$} & \multirow{2}{*}{$\begin{array}{c}2009- \\
10\end{array}$} & \multirow{2}{*}{$\begin{array}{c}2010- \\
11\end{array}$} & \multirow{2}{*}{$\begin{array}{c}2011- \\
12\end{array}$} & \multirow{2}{*}{$\begin{array}{c}2012- \\
13\end{array}$} & \multirow{2}{*}{$\begin{array}{c}2013- \\
14\end{array}$} & \multirow{2}{*}{$\begin{array}{l}2014- \\
15\end{array}$} & \multirow{2}{*}{$\begin{array}{c}2015- \\
16\end{array}$} \\
\hline & $2013-14$ & 2014-15 & $2015-16$ & & & & & & & & & \\
\hline \multirow[b]{2}{*}{$\begin{array}{l}\text { Synthetic } \\
\text { Fibers }\end{array}$} & \multirow[b]{2}{*}{3854} & \multirow[b]{2}{*}{4298} & \multirow[b]{2}{*}{4307} & Production & 2479 & 2835 & 3123 & 3105 & 3124 & 3144 & 3527 & 3554 \\
\hline & & & & $\begin{array}{c}\text { Growth rate } \\
(\%)\end{array}$ & -6.8 & 14.4 & 10.2 & -0.6 & 0.6 & 1.3 & 12.2 & 0.8 \\
\hline \multirow[b]{2}{*}{ Polymers } & \multirow[b]{2}{*}{8905} & \multirow[b]{2}{*}{8905} & \multirow[b]{2}{*}{9768} & Production & 5060 & 5695 & 6343 & 7250 & 7509 & 7876 & 7558 & 8839 \\
\hline & & & & $\begin{array}{c}\text { Growth rate } \\
(\%)\end{array}$ & -4.6 & 12.5 & 11.4 & 14.3 & 3.6 & 8.6 & -4 & 17 \\
\hline \multirow{2}{*}{$\begin{array}{l}\text { Elastomers (S. } \\
\text { Rubber) }\end{array}$} & \multirow[b]{2}{*}{244} & \multirow[b]{2}{*}{425} & \multirow[b]{2}{*}{425} & Production & 96 & 106 & 105 & 100 & 96 & 105 & 172 & 242 \\
\hline & & & & $\begin{array}{c}\text { Growth rate } \\
(\%)\end{array}$ & -8.5 & 10.4 & -0.7 & -4.7 & -4.2 & 4.1 & 64.1 & 40.8 \\
\hline \multirow{2}{*}{$\begin{array}{c}\text { Synth. } \\
\text { Detergent } \\
\text { intermediate }\end{array}$} & \multirow[b]{2}{*}{687} & \multirow[b]{2}{*}{687} & \multirow[b]{2}{*}{687} & Production & 552 & 618 & 638 & 623 & 627 & 597 & 596 & 566 \\
\hline & & & & $\begin{array}{c}\text { Growth rate } \\
(\%)\end{array}$ & -5.7 & 12 & 3.3 & -2.4 & 0.7 & -4.2 & -0.1 & -5.1 \\
\hline \multirow{2}{*}{$\begin{array}{l}\text { Performance } \\
\text { plastics }\end{array}$} & \multirow[b]{2}{*}{2454} & \multirow[b]{2}{*}{2479} & \multirow[b]{2}{*}{2514} & Production & 124 & 1641 & 1740 & 1677 & 1691 & 1685 & 1591 & 1700 \\
\hline & & & & $\begin{array}{c}\text { Growth rate } \\
(\%)\end{array}$ & 8 & 23.9 & 6 & -3.6 & 0.8 & 0.5 & -5.5 & 6.9 \\
\hline \multirow{2}{*}{$\begin{array}{l}\text { Total Basic } \\
\text { Major } \\
\text { Petrochemical }\end{array}$} & \multirow[b]{2}{*}{16144} & \multirow[b]{2}{*}{16794} & \multirow[b]{2}{*}{17702} & Production & 9511 & 10895 & 11950 & 12755 & 13047 & 13406 & 13443 & 14900 \\
\hline & & & & $\begin{array}{c}\text { Growth rate } \\
(\%)\end{array}$ & -3.7 & 14.5 & 9.7 & 6.7 & 2.3 & 2.7 & 3 & 10.8 \\
\hline
\end{tabular}

\section{Factors that shaped this market trend are as follows}

\section{Increase in global demand}

As market surges after 2008-09 crisis, demand for petrochemical products grew as well. This surge in global demand is supplemented by price decrease of crude oil. The consumption demand for 30 plus commodity chemicals and plastics from the whole world was about 1,128 million metric tons in 2016. In future, this demand is expected to grow at a mean rate of about $3.5 \%$ over the next five years, which amounts to over 1300 million metric tons. This 3.5\% rate coincides with 2011-2016 period rates. In this historical period, such rate stood at $3.4 \%$ level. Across the world; it is believed that ethylene demand will increase at a CAGR of 5-6\% and propylene demand at a CAGR of 5.5\% for the period 2014 through 2018. Both will continue to have a significant share of about $70 \%-75 \%$ of overall petrochemical demand.

\section{Capacity expansion}

As per an estimate, 37\% of world demand will be in China by 2021 (Reference). The theory of gravity model of international trade suggests India can fill the gap of demand and supply in China with a lower transportation and manufacturing cost. The Middle East, North America and others comprise the remaining 50 percent demand growth. West Europe's chemical demand growth is projected to grow slowly because the structural issues are affecting the broader economic outlook. Even India's domestic demand is increasing for the petrochemical products. These future concerns led petrochemical industry to expand the capacity to meet the expected future demand rise.

\section{Increase in industrial demand}

IIP registered a 25 months high growth rate of $8.4 \%$ of manufacturing growing at $10.2 \%$ in Nov. 2017. Higher growth in capital goods, construction and consumer non-durables have had a significant impact. Rapid growth in service sector causes demand for office spaces. The per capita electricity consumption of India increased, and it stood in 2014-15 at 1010Kwh. These estimates clearly show that growth of industrial sector that prompt the growth of petrochemical industry.

\section{Technology trends:}

Because of technical innovations in the petrochemical sector, the usage of low density polyethylene is vastly replaced by the linear low density polyethylene in India. Only 1ton of ethylene is required to produce 1 ton of linear low-density polyethylene (LLDPE) whereas more than 1 ton of ethylene was required to 
produce 1 ton of LDPE. India's ONGC Petro additions Limited (OPaL) started its two HDPE (high-density polyethylene)/LLDPE swing units with nameplate capacities of 360,000 tons/year each and a 340,000 tons/year stand-alone HDPE facility in the February of 2017. India's Reliance Industries limited was also expected to startup its LDPE and LLDPE/HDPE units with a combined capacity of $1.1 \mathrm{~m}$ tons/year in the first half of 2017.

\section{Nature of Research and Development (R\&D) in India}

The chemical sector of India, from its very beginning, has regarded science and technology (S\&T) as a substantial contributor to its economic growth. The scientific knowledge applied in the production activities of India vary from sector to sector. Generally, sources of technology are domestic in nature in smaller or downstream petrochemical companies. This is contrary to medium and large scale companies where technologies are imported from overseas agencies. Petrochemical industry is oligopolistic in nature as it has 4-6 major players, so this sector contains large scale companies where technology are imported from foreign. Almost $84 \%$ of chemical sector R\&D expenditure is borne by the firms dealing with knowledge intensive chemical sector with drugs/pharma accounting for almost $60 \%$ of this expenditure. The basic chemical sector requires R\&D for its manufacturing process enhancements to control and reduce expenses and to promote downstream application demand in the market. This sector is yet to optimally utilize R\&D for process intensification and to achieve environment friendly processing. The specialty and knowledge intensive chemical sectors require R\&D for product improvement as well as have scope for process innovations for cost savings. And in order to promote the quantity and quality of petrochemical sector, several steps and schemes has been taken by the Government of India. These schemes comprise tax relaxation of up to $200 \%$ to petrochemical sector if it outsources projects to academic institutions. However, such steps have not proved much fruitful, as the impact of these schemes on Indian petrochemical sector has been marginal. [3]

\section{Technological Choices Available to the Petrochemical Sector of India}

The policies pursued after liberalization significantly enhanced the choices to access the best technology from their foreign counterpart.

i. $\quad$ Firm size has most significant impact on technological choices. These technological choices are limited to large petrochemical companies. In plastic industry most of the firms are medium-and-small enterprises (MSE) and doesn't have enough earning to spend on technological advancements [4]

ii. According to the report entitled Chemicals \& Petrochemicals Statistics at a Glance (2016) [5], the odds in favor of licensing foreign technologies and hence combining them with their R\&D efforts has increased because of Foreign Equity participation.

\section{Determinants of R\&D Expenditures in Petrochemical Industry in India}

i. Retained earnings-no firm wants to lose their earnings on paying interest on a project whose outcome is uncertain and awaited for an uncertain period of time [6]

ii. Competitiveness-petrochemical firms in India share oligopolistic market power where price remains same or rigid. So degree of competition does not force them to expand a significant amount of their earnings on R\&D. The competition from foreign firms is also not significant because firms in petrochemical industry are either private or semiprivate [7]

iii. High Sinking Cost-failure of $R \& D$ projects can lead to a significant amount of losses to the stack-holders, so firm believes more in importing the technology which is tested.

\section{Innovation Climate in Other Countries Vis-À-Vis India}

Table 2: Innovation ecosystems in 5 countries, 1996 [8].

\begin{tabular}{|c|c|c|c|c|c|c|}
\hline & Singapore & Malaysia & India & $\begin{array}{c}\text { South } \\
\text { Africa }\end{array}$ & Brazil \\
\hline & $\begin{array}{c}\text { Density } \\
\text { of R\&D } \\
\text { scientists } \\
\text { (No per } \\
10000 \\
\text { labor) }\end{array}$ & 56.3 & 5.1 & 8.24 & 20 & 7 \\
\hline 2 & $\begin{array}{c}\text { US patents } \\
\text { granted }\end{array}$ & $54(37)$ & $7(0)$ & $22(50)^{*}$ & $67(28)$ & $37(35)$ \\
\hline & $\begin{array}{c}\text { High-tech } \\
\text { Exports } \\
\text { (\%) }\end{array}$ & 55.7 & 44.4 & 6.9 & 5.7 & 6.25 \\
\hline
\end{tabular}

Note: numbers in parenthesis indicate \% share of local companies ${ }^{*}$ Local companies $+\mathrm{R} \& \mathrm{D}$ institutes

In Table 2 above [8] made a comparative analysis of the impact made by national S\&T policies (fiscal and non-fiscal) of south Africa, Singapore, India, Malaysia and Brazil on the innovation in manufacturing firms considering various components of their cognizance generation systems. Fiscal measures consist of two important economic actions: (1) tax incentives directed to promote investments in the area of Research and Development (R\&D); (2) grant-in-aid for research projects of industrial relevance. Nonfiscal measures include: (1) creation and generation of human resource development through skill development; (2) industryacademic linkages through various means such as memorandum of understandings (Mo U), etc. Recognizing the role of R\&D scientist's and advanced-technology content of their export products and their innovation policies, he concluded that Singapore has an effective innovation policy. This policy has been maintained by the Singapore Government to raise its research intensity. Even though Malaysia and South Africa have established a variety of research grants to brace R\&D projects, still they have not been successful in making a major impact due to shortage of appropriately qualified human resource. Though Brazil and India have a vast pool of Science and Technology (S\&T) manpower and research infrastructure, their 
availability is not adequate to manufacturing companies for doing R\&D. They need to work on their non-fiscal measures. Following observations, which were applicable for 1978-99 periods, are still relevant for India:

i. Poor administration of direct and indirect tax incentives on R\&D: In every budget government raised the incentives to the petrochemical sector but poor administration; high ladders to get the benefits make the facilities less attractive for the producers.

ii. Research grants are aimed at technological self-reliance and not global competitiveness: In India grants to major players like Indian petrochemical cooperation limited is not much higher. They can increase the production but cannot compete with the foreign majors. These less grants are resisting these sectors competitiveness.

iii. Non-fiscal instruments need to be strengthened: Nonfiscal instruments such as patents, licensing, and copyright policies are still a subject of discussion in Indian context because last amendment in Indian Patent Law was in 2005 .

\section{Key Challenges}

i. Volatility of raw material prices: India has 4 naphtha based cracker complexes. Naphtha is a crude oil derived product. The prices of crude oil witnessed a significant volatility, thereby making petrochemicals prices highly volatile.

ii. Increased competition from abroad: Over the time, the production capacity has been increasing incessantly in ethane rich Middle East and shale gas rich US. Such a production (Shale gas) edge to the US has generated a competitive advantage to the US petrochemical sector. For instance, out of the 30 million tons of ethylene capacity additions expected during the period 2014 and 2018, 12.5million tons were expected in the US alone. Since, ethane and shale gas based petrochemical products are cheaper than petrochemical products in India domestic producers are expected to witness margins pressure [9]

iii. Limited capacity of petrochemical intermediate sector: As several growth reports suggested that India's projected growth is high so the demand for petrochemical products will increase over time. Petrochemical sector uses acetic acid, acrylic acid and propylene oxide as intermediary products. The compatibility to keep up the production with demand is not very good [solving the puzzle of India's petrochemical-intermediate shortfall [10].

iv. New reserves discovery: Crude oil is a natural resource so its supply is limited. To keep the sector competitive, Indian firms need to find new reserves. Already, the search initiative has been taken by Oil and natural gas corporation (ONGC) for such reserves in the Indian Ocean.

v. Pollution: Petro products, for example plastic, Vaseline etc. are derived from natural products namely crude oil natural gas or uses natural resources as inputs. Extraction and production cost must be determined or adjusted according to environmental pricing principles such as Pigovian taxation, Coase Principle, etc. [11]

vi. Effective regulation through a proper institution: Natural resources are wealth for a country, particularly when such resources are scarce in quantity. So every country wants them to regulate as per the rules to maintain intergenerational equity. Hence, India needs a legal autonomous institution to regulate this sector.

vii. Budgetary allocation: Allocations in budget is still far less than other sectors. So policy makers need to target this sector as well.

viii. Poor infrastructural facilities: India has poor physical infrastructure and even pace to construct these basic facilities for business is very limited [9]

ix. Uninterrupted power supply: In India rate of growth of power generation is not same as the growth rate of demand. So Indian petrochemical sector faces interrupted power supply and unexpected power cuts. This power problem/shortage of power is a key challenge for developing country like India which is facing high competition from China, Brazil, and Singapore [9].

\section{Conclusion}

This is evident from changing market structure of petrochemical industry that to meet the global demand and competitiveness Indian petrochemical industry need policy boost up through strengthened administration, revival of non-fiscal and fiscal instruments to incentivize more research and development (R\&D) projects. India needs skilled labor force to grab the benefits, and in order to do so we need more specialized academic institutions such as Central Institute of Plastic Engineering\& Technology (CIPET) because Academic participation in R\&D has a multiplier effect.

\section{References}

1. Sateesh K (2015) A Brief Report on Chemical and Petrochemical Industry in India. ASA \& associates, Hyderabad, India.

2. AIPC (2017) Indian petrochemical industry review of 2016-17 \& outlook for 2017-18. AIPC 2017 Country Paper from India. Chemicals and Petrochemicals Manufactures Association, Asia Petrochemical Industry conference, Japan.

3. Raghavan (2011) R\&D Impact on Indian chemical industry. Indian National Academy of Engineering, New Delhi.

4. FICCI (2014) Potential of Plastics Industry in Northern India with special focus on Plasticulture and food Processing-2014. A Report on Plastics Industry, Tata Strategic Management Group, India.

5. Government of India (2016) Chemicals \& Petrochemicals Statistics at a Glance: 2016. Government of India, Ministry of Chemicals and Fertilizers.

6. Hay DA and Morris DJ (1991) Industrial Economics and organization: theory of evidence. Oxford University Press, India.

7. Arrow K (1962) Economic welfare and allocation of resources for invention. Economic and Social Factors, NBER, Princeton University Press, USA. 
8. Mani S (2002) Government, Innovation and Technology Policy: An International Comparative Analysis. Edward Elgar Publishing Limited, Cheltanham, England, UK.

9. FICCI (2014) Handbook on Indian Chemicals and Petrochemicals Sector
10. Goyal A, Kotecha S, Simons TJ (2015) Soling the puzzle of India's petrochemical-intermediate shortfall. McKinsey and Company, USA.

11. Coase RH (1960) The problem of social cost. The Journal of Law \& Economics 3: 1-44. (c) (i) Creative Commons Attribution 4.0

For possible submissions Click Here

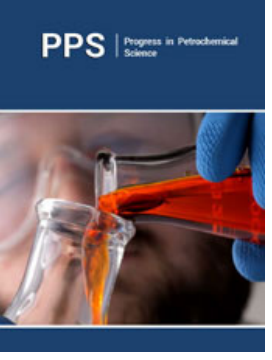

\section{Progress in Petrochemical Science}

\section{Benefits of Publishing with us}

- High-level peer review and editorial services

- Freely accessible online immediately upon publication

- Authors retain the copyright to their work

- Licensing it under a Creative Commons license

- Visibility through different online platforms 